\title{
Association Among some carcass traits in Three Weight Groups of Pigs
}

By

\author{
B. L. Fetuga, G. M. Babatunde, \\ O. AYENI* and V. A. OYENUGA \\ Department of Animal Science, \\ University of Ibadan, \\ Ibadan, Nigeria.
}

SUMMARY

A TOTAL of seven hundred and eight Large White $\mathrm{x}$ Landrace pigs were slaughtered at three weight groups, $34.0,55.0$ and $92.0 \mathrm{~kg}$ to collect carcass data. Of these 228 , made of 118 castrates and 110 gilts, were slaughtered at $34 \mathrm{~kg} ; 240$ pigs, made up of 125 castrates and 115 gilts were slaughtered at $55 \mathrm{~kg}$, while a total of 240 pigs made up of 120 gilts and 120 barrows were slaughtered at $92 \mathrm{~kg}$. Simple correlations as well as regression equations describing relationship among traits were calculated.

Percent of lean cuts and separable lean in carcass decreased while fat cuts and separable fat increased with increasing slaughter weight Such linear measurements as backfat thickness, loin-eye muscle area and carcass length increased significantly with increasing slaughter weights. Significant differences were obtained for several carcass traits between castrates and gilts slaughtered at $92 \mathrm{~kg}$

Among the carcass cuts, percentage four lean cuts and loin showed highly significant and positive correlations with separable lean, while the relationship for other cuts such as the ham and shoulder, though significant, were low. Such carcass fat predictors as percentages separable fat, fat cuts and trimmed fat as well as backfat thickness were highly significantly negatively correlated with separable lean, the relationship being highest for percentage separable fat. Dressing percentage and carcass length were poorly correlated with fatness or leaness, while loin eye areas was highly significantly correlated with leaness. The predictive values of the different traits remained relatively the same at the different slaughter weights, although the relationships were better at the $55 \mathrm{~kg}$ slaughter neight than at lower weights. The results indicate that while direct chemical determinations or complete physical separation are considered the best measures of carcass quality, the magnitude of the correlation coefficients between separable lean or fat and the different cuts suggests that these could be used with some degree of precision in appraising carcasses.

\section{INTRODUCTION}

COMPLETE physical separation of the carcass into lean, fat and bone is perhaps the most accurate measure of fat and lean tissue distribution in pigs. This is however expensive and rarely used except in detailed experimental studies. From the commercial standpoint the ultimate criterion of carcass merit is economic value and this is largely determined by the proportion of commercial cut-out yield that is available for sale. Evaluation of such yields from carcass measurements in market weight pigs is not new (Freden, Berg, Bowland and Doornenbal, 1964 and Buch, Harrington and Johnson, 1962). Appraisal of carcass leaness from chemical analysis has also been reported (Doornenbal and Martin, 1966; Babatunde et. al., 1966). While several other chemical and physical parameters such as blood characteristics (Doornenbal and Frankman, 1970), muscle fibre diameter (Berry, Hillers and Kroening, (1968), depth of chine bones (Orme et al. 1959) and other techniques (Doornenbal, Wellington and Stouffer, 1962, Hetzer and Millers 1972) have been recognised as predictors of carcass merit. These estimates have however been mainly applied to market weight pigs. Only limited information is available as to the effects of much lower slaughter weights on carcass characteristics and relationships.

"Department of Preventive and Social Medicine, University College Hospital, Ibadan.

Nigerian Journal of Animal Production (2) 21976 
Moreover, up to the present time even though there are no carcass standards for pigs and cattle in Nigeria there has been no reason to believe that relationships established for pigs in the temperate environment would be any different from those reared and slaughtered in the tropics. One recent evidence, (Sofoluke and Dettmers, 1973) suggests that carcasses of pigs presently produced in this country are overfat and indicated a need to establish relationships among some carcass measurements for such animals. This particular study however involved too few animals of widely varying weights to make the conclusions valid. Furthermore, the animals used had been subjected to uncontrolled and unstandardised feeding regimes which could not be said to represent standard husbandry and feeding practices in most units. The present study was, therefore, conducted to investigate the relationship among carcass traits at varying weights usually encountered in experimentation and to reassess the claim by Sofoluke and Dettmers (1973), that pigs reared under the conditions prevalent at Ibadan are overfat using a larger number of animals under standard feeding regimes.

\section{MATERIALS AND METHODS}

A total of seven hundred and eight Large White $\mathrm{x}$ Landrace pigs were slaughtered at 34,55 and $92 \mathrm{~kg}$ to collect carcass data. Two hundred and twenty eight pigs made up of 118 castrates and 110 gilts were slaughtered at $34 \mathrm{~kg}, 240$ pigs made up of 125 castrates and 115 gilts were slaughtered at $55 \mathrm{~kg}$, while a total of 240 pigs made up of 120 barrows and 120 gilts were slaughtered at $92 \mathrm{~kg}$.

All pigs were reared from weaning on $24 \%$ crude protein weaner's ration of the following percentage composition: Yellow maize, $64.0 \%$; groundnut cake, $20.0 \%$; fishmeal, $3.0 \%$; blood meal, $3.0 \%$; rice bran, $2.0 \%$; skim-milk powder, $2.0 \%$; palm oil, $2.5 \%$; dicalcium phosphate $3.0 \%$; salt, $0.5 \%$ and Vitamin-trace mineral mixture at the rate of $5 \mathrm{~kg} /$ ton of feed calculated to supply the following per $\mathrm{kg}$ of ration: Vitamin A, 8,000 IU; Vitamin $\mathrm{D}_{3}, 550 \mathrm{IU}$; Zinc, $200 \mathrm{mg}$; Oxytetracyline hydrocholoride, $4 \mathrm{mg}$; and all other members of the B-complex vitamins at levels slightly higher than the minimum recommended levels. All pigs slaughtered at 34 and $55 \mathrm{~kg}$ liveweights received the above diets throughout. The pigs slaughtered at $92 \mathrm{~kg}$ received the above diets until they attained $45 \mathrm{~kg}$ liveweight, when they were switched over to a growing-fattening diet containing $18 \%$ crude protein. The reduction in protein level in the diet was effected by a total removal of fishmeal and a reduction in the level of groundnut meal. Water and feed were provided ad libitum.

Pigs were slaughtered as they attained the predetermined slaughter weights, after deprivation of feed, but not water for 18 hours. Immediately after slaughter and dressing, the dressed carcasses were split into two longitudinal halves. The right side was immediately dissected into lean, fat and bone, while the left half was chilled for 24 hours at about $-5^{\circ} \mathrm{C}$, after which the following conventional carcass measurements were taken: length from the anterior end of the first rib to the anterior end of the aitch bone of the pelvis; average backfat thickness opposite the first and last ribs, and the last lumbar vertebra; the loin-eye area calculated from the planimeter tracing of the longissimus dorsi muscle sectioned at the tenth rib; the percentage yields of the trimmed ham, loin, and the shoulder cuts, the belly, the jowl, and the trimmed fat percentage. 
Correlation amongst carcass traits were determined for the pooled data disregarding sex for the 34 and $55 \mathrm{~kg}$. slaughter weights, while for the $92 \mathrm{~kg}$, weight, correlations were determined separately for males and females as well as for the pooled data disregarding sex. Estimates of regression coefficient and intercept and slope of regression equations were made according to standard procedures (Steel and Torrie, 1960).

\section{RESULTS AND DISCUSSION}

Some selected carcass traits for Large White $\mathrm{x}$ Landrace pigs slaughtered at 3 different weight groups are summarised in table 1. Percent lean, ham, shoulder, four lean cuts decreased as slaughter weights increased, while the percent fat and fat cuts increased progressively with increasing slaughter weight. At heavier weights carcass length, mean backfat thickness, percent trimmed fat loin-eye muscle area were higher than at lower weights. The magnitude of the differences was greater and highly significantly $(\mathrm{P}<$ $0.01)$ greater for the $92 \mathrm{~kg}$.-slaughter group compared to the $34 \mathrm{~kg}$ slaughter group. A comparison of the 34 and $55 \mathrm{~kg}$ slaughter groups showed significantly ( $\mathrm{P}<0.05$ ) higher backfat thickness, percent trimmed fat, loin-eye muscle area and carcass length for the latter group. These results agree well with the earlier findings of Babatunde et. al. (1966), and Emerson et al. (1964) who found that, as slaughter weight was lowered from 93 to $45 \mathrm{~kg}$., there was a decrease in carcass length, dressing percent and loin-eye muscle area and an increase in the percent of primal and lean cuts. Various other studies have illustrated that pigs of less than normal slaughter weight produce leaner carcasses (Field et. al., 1961, Varney. et. al. 1962). Compared to the data of Sofoluke and
Dettmers (1973), the proportion of the different tissues obtained by gross carcass dissection were remarkably different. The lean percentages in dressed carcass obtained in the present study were 61.87 , 61.83 and $58.39 \%$ for the 34,55 and $92 \mathrm{~kg}$. slaughter weights respectively compared to the value of $40.62 \%$ estimated by these authors to be present in pig carcasses slaughtered at liveweights ranging between 64 and $103 \mathrm{~kg}$. Carcass yield reported by these authors was low in comparison to the mean values reported in our study (Table 1). Mean percentage fat plus skin at 34,55 and $92 \mathrm{~kg}$. slaughter weights reported in this study were 23.35 , 24.81 and $30.10 \%$ respectively compared to a mean value of $44.14 \%$ reported by Sofoluke and Dettmers (1973). The gross composition presented in their study is quite suprising, since their very low dressing $\%$ of 70.09 and backfat thickness of $2.82 \mathrm{~cm}$. should be indicative of a lean carcass. Contrary to the views expressed by these authors the carcasses obtained from pigs properly fed and well managed were comparable to those of a similar breed managed and slaughtered elsewhere in the temperate Countries. For the $92 \mathrm{~kg}$. slaughter group which approximates to the market weight of pigs in the United States, the loin-eye muscle area, carcass length and mean backfat thickness of $23.57 \mathrm{~cm}^{2}, 78.63 \mathrm{~cm}$ and $3.17 \mathrm{~cm}$ respectively fall within the range of $22.6 \mathrm{~cm}^{2}$, $76-81 \mathrm{~cm}$ and $2.8-3.6 \mathrm{~cm}$ for the corresponding measurements required of a medium pig. Based on records from some Danish test stations and data from British experiments, Harrington (1958) gives the dressing percentage of Large White and Landrace pigs slaughtered between 41 and $79 \mathrm{~kg}$. as $75-80 \%$ and $73.5 \%$ respectively. The dressing percentages presented in our study for Large White $\mathrm{x}$ Landrace crosses are in agreement with these values. 


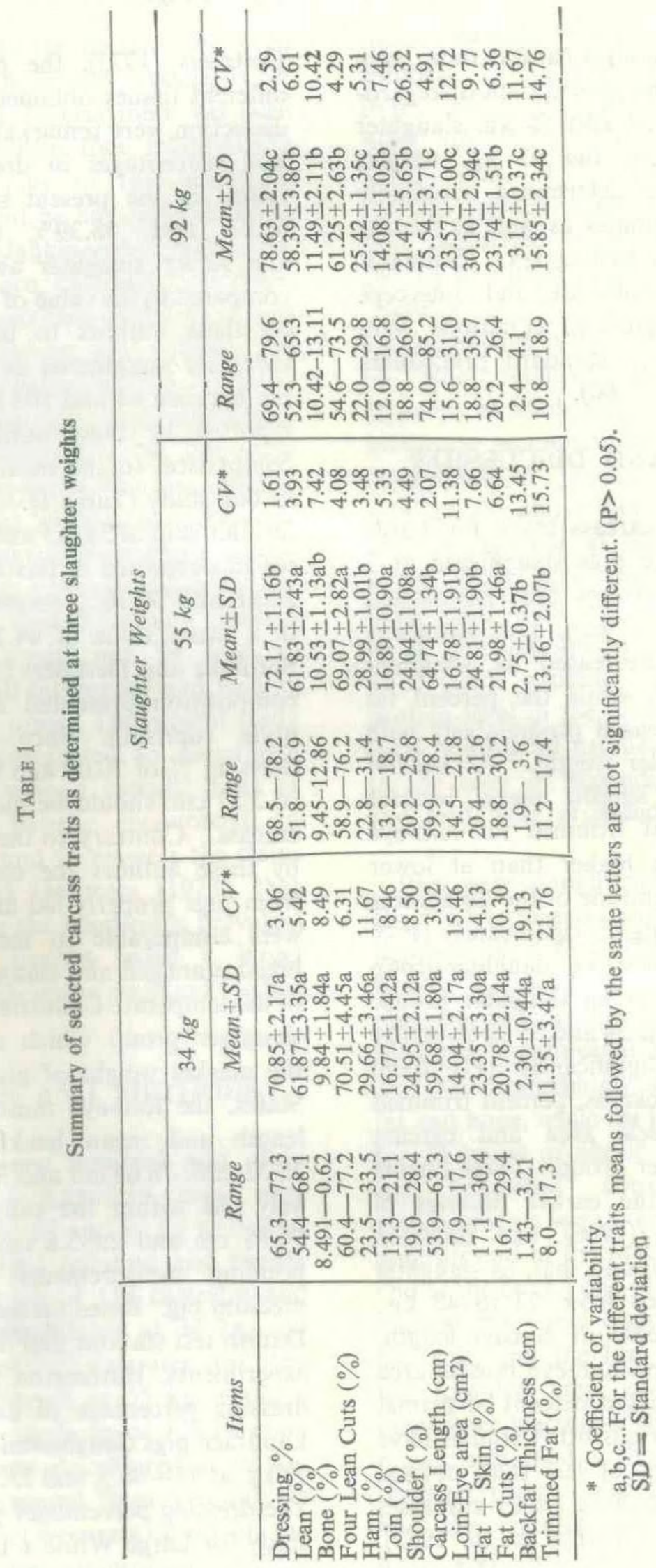


There is no physiological bases for the expectation that pigs reared in the hot humid tropics would be fatter, quite apart from the inadequate nutrition which we presume could have been a major problem with the pigs used in the report by Sofoluke and Dettmers (1973). The data presented by us tend to indicate the production of leaner pig carcasses under the conditions that prevail at Ibadan relative to reports from the temperate countries, under proper nutritional and management regimes. This proposition is particularly strengthened by the fact that fat deposition is more likely to be favoured in colder climates where fat deposition as an additional insulation against cold is quite likely. Heat dissipation is a problem for pigs in the tropics and under situations of balanced feeding, excessive fat deposition is not likely to be favoured. The nature and extent of fatty tissue deposits is vitally related to ability to be buffered against cold stress. Some studies exist on the effects of environmental temperatures on carcass quality in pigs. Sorensen (1962), had suggested from his studies, that pigs in a cold environment may produce fatter carcasses than pigs in a warm environment, when rates of gain are similar for both. Contrary to this suggestion Seymour Speer, Hays, Mangold and Hazen (1964), Jensen et. al. (1963) Grosse and Pfeiffer (1963) and Holmes and Coey (1967) found that environmental temperatures per se have little effects on carcass composition.

A summary of selected carcass traits for castrated male and female Large White $\mathrm{x}$ Landrace pigs slaughtered at $92 \mathrm{~kg}$. liveweight appear in table 2. The females had significantly $(\mathrm{P}<0.05)$ lower percent fat cuts, dressing percent, backfat thickness and higher percent lean and loin-eye muscle area than castrates while percentages lean cuts, ham and loin were highly significantly $(\mathrm{P}<0.001)$ higher for females than for castrates. Percentages fat plus skin and trimmed fat were highly significantly higher for castrates than for females. These observations with respect to sex influences on carcass quality are in complete agreement with the report by Lodge (1969), that female pigs were leaner than castrated males. The sex differences in carcass leaness observed are also in general accord with the scientific evidence as reviewed by Field (1971.

Relationships between some linear measurements, gross composition and carcass cuts for pigs slaughtered at $34 \mathrm{~kg}$ liveweight are presented in table 3 . The lean cuts as percentage of chilled carcass weight, loin and loin-eye muscle area showed highly positive relationships with actually dissected lean while for others such as the ham and shoulder, though the relationships were significant, were as low as not to be regarded as good predictors. Percent four lean cuts was negatively correlated with the fat parameters which is in agreement with the observations of Zobrisky et.al. (1954) and since confirmed by others (Gnaedinger et. al. 1963; Doornenbal, 1961) that the percent lean cuts is inversely associated with backfat and percent belly and directly associated with the lean traits. Such fat prediction traits as percentages fat, fat cuts, trimmed fat and backfat thickness were highly significantly negatively correlated with carcass leaness. Actually dissected fat showed the highest correlation, followed by percent trimmed fat and then backfat thickness. The superior correlation of trimmed fat to percentage separable lean and lean cuts compared to mean backfat thickness may be related to the built-in-part-whole relationship between these variables. Smith and Carpenter (1973), had observed that fat thickness measured at three locations opposite the 


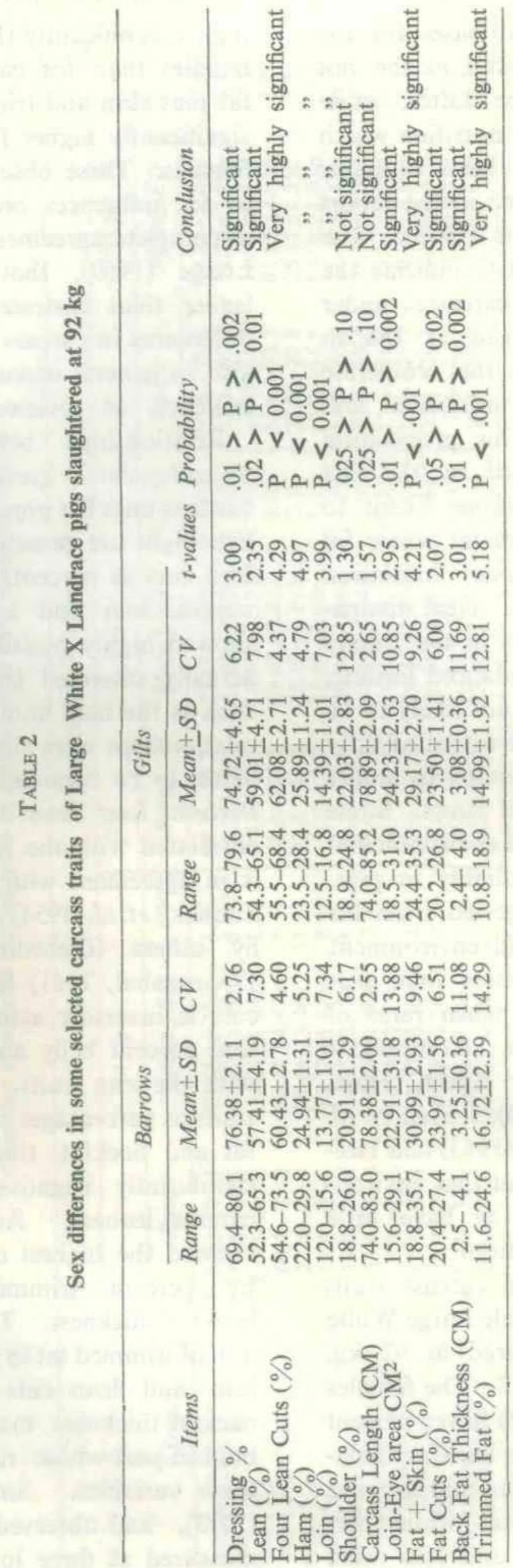


Carcass Relationships in Pigs

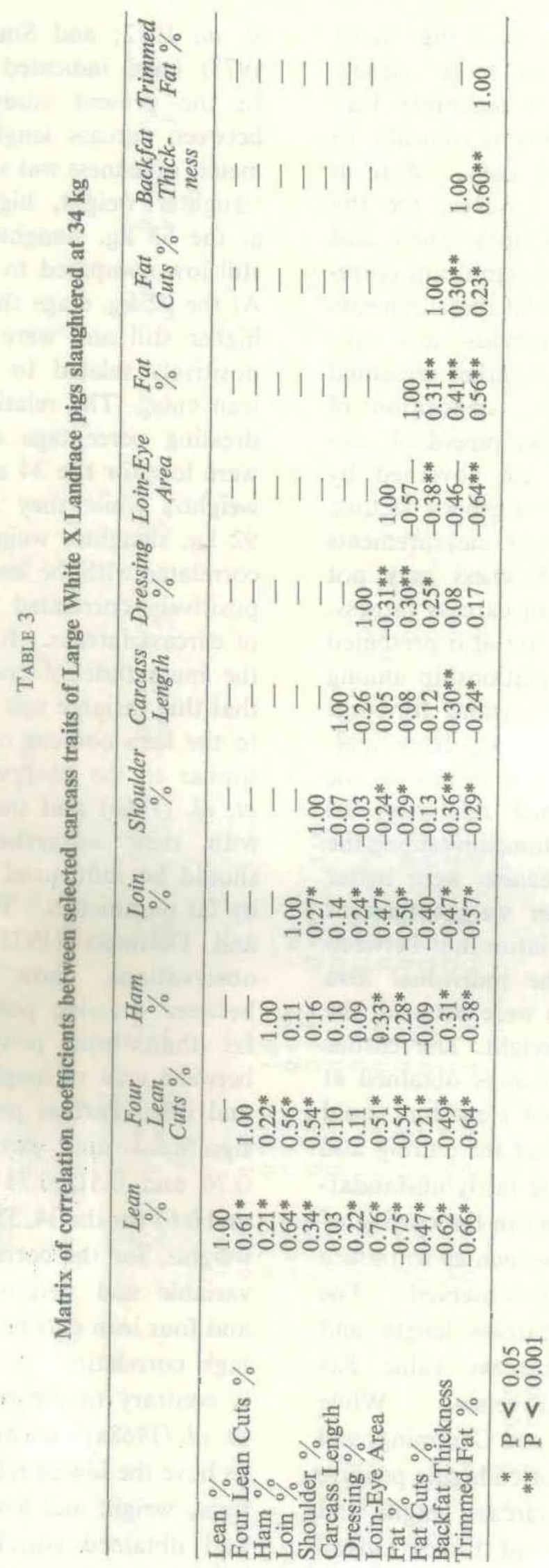


longissimus dorsi muscle was the single measurement which was most closely related to percentages of separable lean and four lean cuts. This is contrary to the observations in this study. More in line with our finding however, are the results of Doornenbal (1967), which had clearly indicated low but significant correlations between external fat measurements and total fat in the carcass and cuts. Duniec et. al. (1961), had earlier presented data suggesting that the deposition of internal fat and the development of subcutaneous fat in pigs are governed by different physiological and genetic factors, thus suggesting that linear measurements of subcutaneous fat thickness may not accurately predict overall carcass fatness. Correlation coefficients are also presented in tables 4 and 5 for relationship among several selected carcass traits for pigs slaughtered at 55 and $92 \mathrm{~kg}$. liveweight. In general, the predictive values of the different traits remained relatively the same, although the relationship among the various measures of leaness were better at the $55 \mathrm{~kg}$. slaughter weight than at lower weights. The relationship between separable lean and the individual lean cuts and four lean cuts were better at the $55 \mathrm{~kg}$. than the $92 \mathrm{~kg}$. weight. The reasons for these lower relationships obtained at the higher weight is not clear but could be related to the fact that the cutting and trimming procedures are fairly unstandardised and that the errors in the cutting of larger carcasses may be such as to induce the lower relationships observed. The relationship between carcass length and other measures of carcass value has remained fairly controversial. While Engleman et. al. (1950) and Cummings and Winters.(1951) had reported highly positive correlations between carcass length and carcass leaness, more recent studies (Lidvall et. al. 1972; and Smith and Carpenter, 1973) have indicated low relationships. In the present study, the relationship between carcass length and other parameters of leaness was very low at the $34 \mathrm{~kg}$. slaughter weight, higher and significant at the $55 \mathrm{~kg}$. slaughter weight, although still low compared to several other traits. At the $92 \mathrm{~kg}$. stage the relationships were higher still and were highly significantly positively related to separable lean and lean cuts. The relationship between the dressing percentage and other variables were low for the 34 and $55 \mathrm{~kg}$. slaughter weights, while they were higher at the $92 \mathrm{~kg}$. slaughter weight, being negatively correlated with the lean measurements and positively correlated with the predictors of carcass fatness. It would appear from the magnitude of correlation coefficients that this variable was more closely related to the lean content of the body. This is similar to the observation of Babatunde et. al. (1966) and therefore more in line with their suggestion that this trait should be influenced more by lean than by fat parameters. The data of Sofoluke and Dettmers (1973), contrary to our observations, show greater relationship between dressing percentage and carcass fat than lean percent. Relationship between area of longissimus dorsi muscle and other carcass predictors were highly significant and positive. These were 0.76 and $0.51,0.74$ and 0.74 and 0.47 and 0.67 for the 34,55 and $92 \mathrm{~kg}$. slaughter weights, for the correlations between this variable and percentage separable lean and four lean cuts respectively. The fairly high correlations obtained in this study is contrary to the observations of Berry et. al. (1968a) that loin-eye area appeared to have the lowest relationships with other sizes, weight and length variables. They had obtained correlation coefficients of 
Carcass Relationships in Pigs

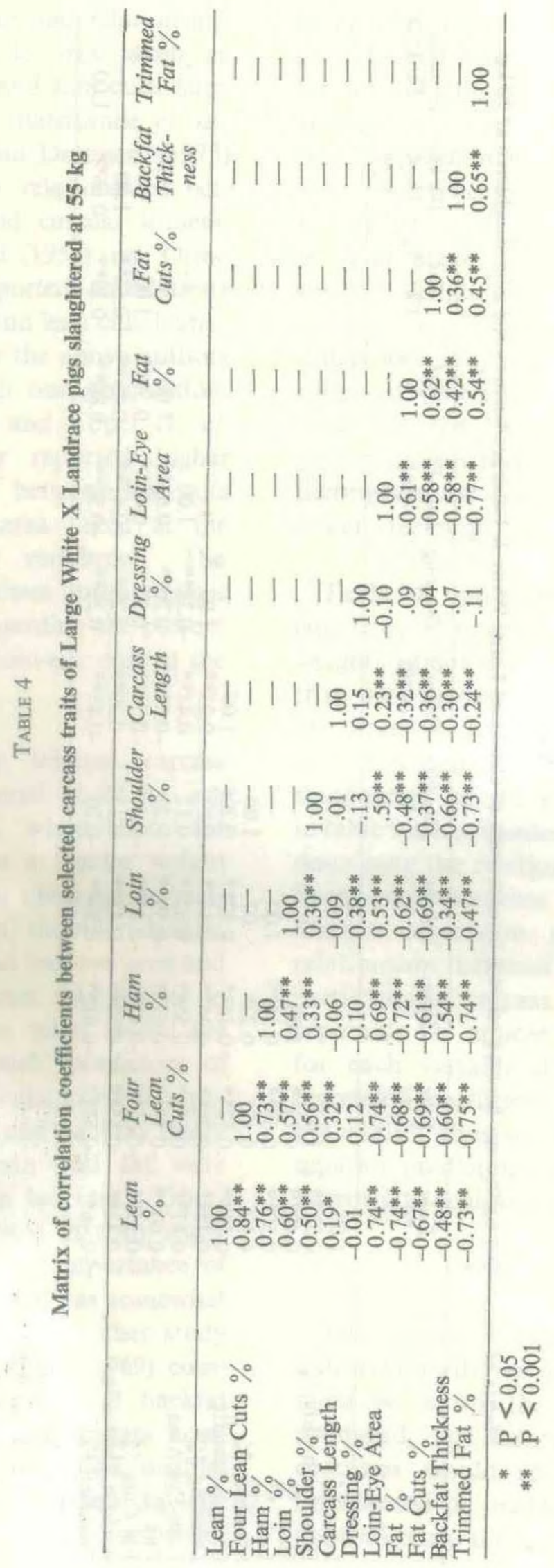




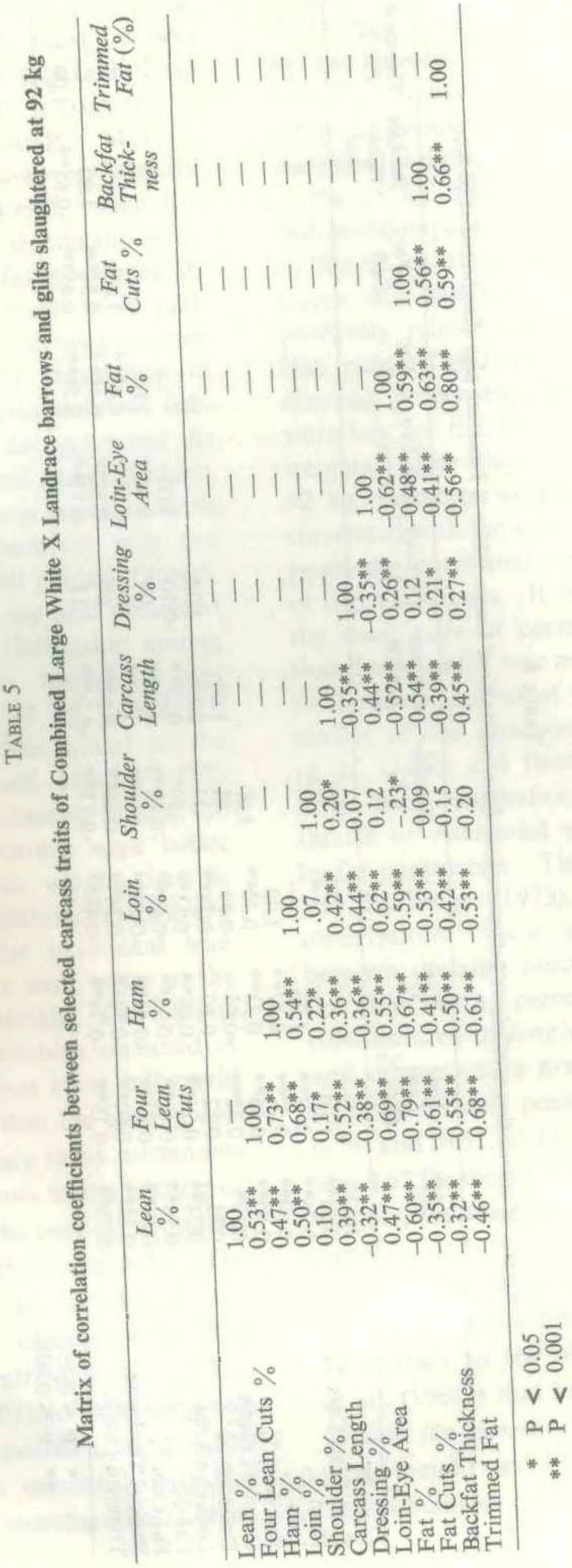


$0.24,0.29$ and 0.52 for the relationship between loin-eye muscle area taken at opposite the tenth rib and lean cuts, ham and loin respectively. Babatunde et. al. (1966) and Sofoluke and Dettmers (1973) had also reported low relationships between this variable and carcass leaness, while Kline and Hazel (1955) an Orme et. al. (1967) had reported correlations between loin-eye area and lean cuts higher than those reported by the above authors and more in line with our observation. Berry et. al. (1968b) and Topel et. al. (1965), have however reported higher correlation coefficients between lean cuts and loin-eye muscle area taken at the 14th and 1st lumbar vertebrae. The evidence presented by these authors raises important questions regarding the present practice of measuring loin-eye area at the 10 th rib.

Relationship among selected carcass traits for gilts slaughtered at $92 \mathrm{~kg}$. are presented in table 6 , while those for barrows slaughtered at a similar weight appear in table 7. The observed correlations for lean cuts, loin, shoulder, length, dressing percentages and loin-eye area and separable lean in carcass was higher in the barrows than the gilts, while the relationship between such predictors of carcass fatness as fat cuts, percent separable fat, trimmed fat and backfat thickness and separable lean and fat were higher in the gilts than barrows. Doornenbal and Martin (1966) in their study showed that the order of importance of several predictive variables was somewhat different for each sex. In another study (Doornenbal and Frankham 1969) comparing blood characteristics and backfat thickness as predictors of carcass com, position of market weight pigs, distinct sex differences were obtained in the magnitude of the correlation coefficient, being much higher and generally significant in gilts and low and non-significant in barrows. These reports, while not directly applicable to such measurements as have been applied in the present study, show that differences between sexes exist. Lidvall et. al. (1972), had also observed sex and breed differences in the use of carcass length in predicting carcasscomposition. While the reason for these differences may not be quite clear, the observed differences clearly point to the need for the development of separate prediction equations for each sex in predicting carcass composition from several easier techniques for better precision.

Table 8 summarises the regression equations describing the relationships of weights of some commercial cuts and fat trim with carcass lean in pigs slaughtered at three weights as well as separate predictive equations for gilts and barrows slaughtered at $92 \mathrm{~kg}$. liveweight, while in table 9 are presented regression equation describing the relationships between some linear measurements and separable lean. Similar regression parameters for the relationship between some conventional predictors of carcass fatness and carcass separable fat appear in table 10. These for each variable different estimates of regression coefficients were obtained for both sexes, thus confirming the need for separate prediction equations for gilts and barrows to achieve greater precision.

\section{CONCLUSIONS}

The results presented in this study indicate no adverse influences of environment per se on the type of pig carcass produced, but rather suggest that poor carcasses would result essentially from imbalanced or inadequate nutrition, thus contradicting the evidence presented by 


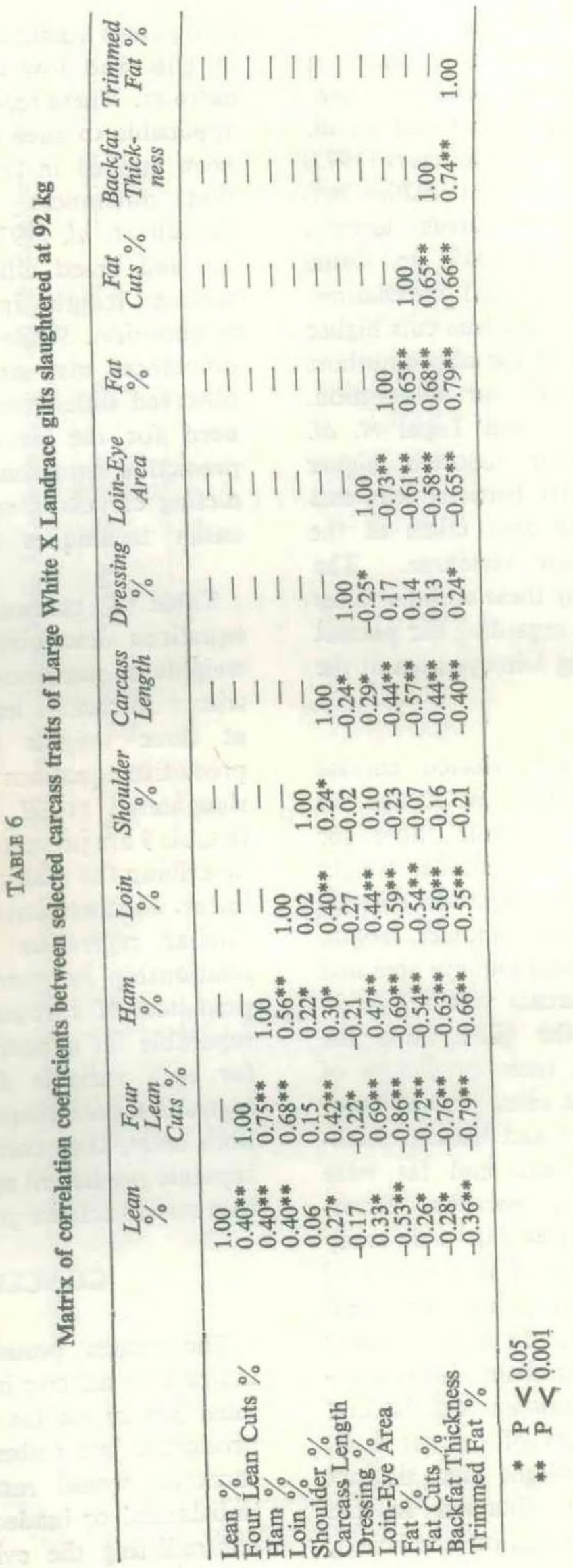


Carcass Relationships in Pigs

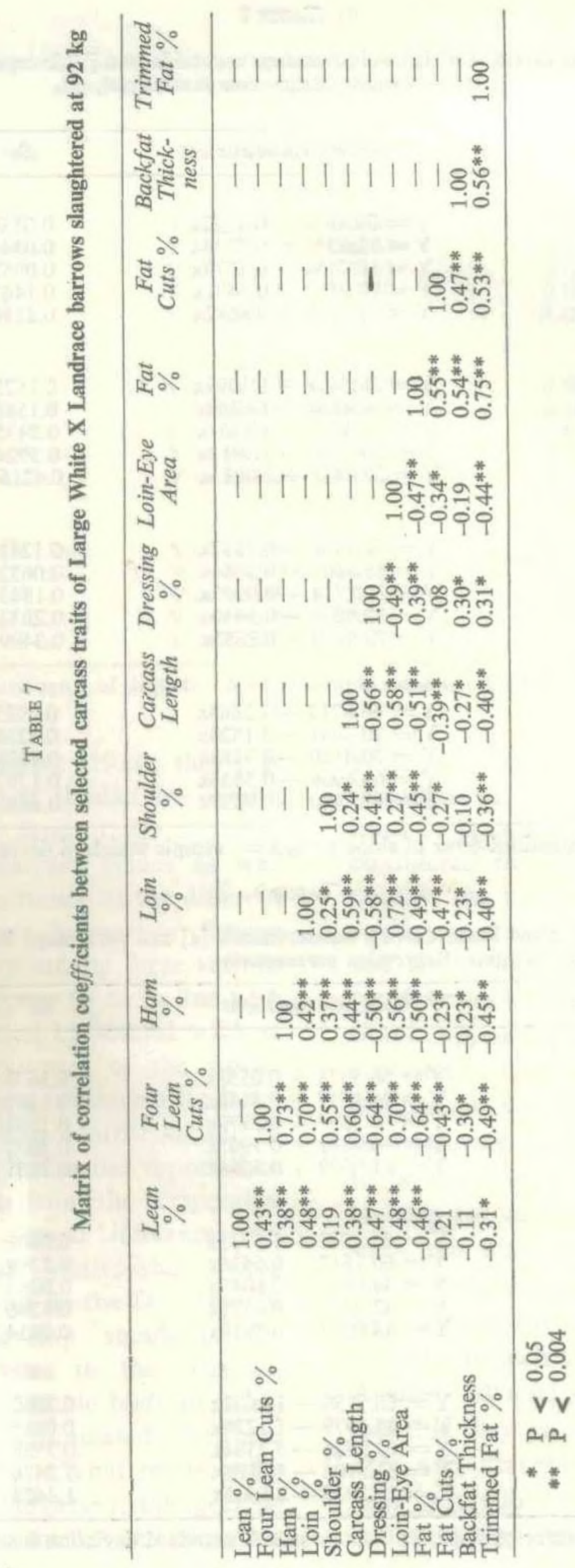


Table 8

Relationship between some carcass cuts $f \mathbf{x}]$ and percentage separable lean $[Y]$ in carcass of pigs slaughtered at three weights (Regression parameters).

\begin{tabular}{|c|c|c|c|}
\hline Carcass cuts & Prediction equations & $S b$ & $S_{y} \cdot x$ \\
\hline Four Lean Cuts & & & \\
\hline $\begin{array}{l}34 \mathrm{~kg} . \\
55 \mathrm{~kg} . \\
92 \mathrm{~kg} . \text { (Pooled) } \\
\mathrm{M} \\
\mathrm{F}\end{array}$ & $\begin{array}{l}\mathrm{Y}=29.4954+0.4592 \mathrm{x} \\
\mathrm{Y}=11.8351+0.7238 \mathrm{x} \\
\mathrm{Y}=10.7454+0.7779 \mathrm{x} \\
\mathrm{Y}=18.2457+0.6481 \mathrm{x} \\
\mathrm{Y}=5.1120+0.8682 \mathrm{x}\end{array}$ & $\begin{array}{l}0.0536 \\
0.0344 \\
0.0952 \\
0.1467 \\
0.2158\end{array}$ & $\begin{array}{l}2.6545 \\
1.3185 \\
3.2733 \\
3.7829 \\
4.3168\end{array}$ \\
\hline $\begin{array}{l}\text { Percent Loin } \\
34 \mathrm{~kg} . \\
55 \mathrm{~kg} . \\
92 \mathrm{~kg} . \text { (Pooled) } \\
\mathrm{M} \\
\mathrm{F}\end{array}$ & $\begin{array}{l}\mathrm{Y}=36.5498+1.5099 \mathrm{x} \\
\mathrm{Y}=34.4682+1.6200 \mathrm{x} \\
\mathrm{Y}=32.5096+1.8381 \mathrm{x} \\
\mathrm{Y}=29.9900+1.9913 \mathrm{x} \\
\mathrm{Y}=27.8421+2.0985 \mathrm{x}\end{array}$ & $\begin{array}{l}0.1628 \\
0.1588 \\
0.2435 \\
0.3924 \\
0.4216\end{array}$ & $\begin{array}{l}2.5741 \\
1.9440 \\
3.3429 \\
3.6758 \\
3.9241\end{array}$ \\
\hline $\begin{array}{l}\text { Percent Fat Cuts } \\
34 \mathrm{~kg} . \\
55 \mathrm{~kg} . \\
92 \mathrm{~kg} \text { (Pooled) } \\
\text { M } \\
\mathrm{F}\end{array}$ & $\begin{array}{l}\mathrm{Y}=77.1588-0.7357 \mathrm{x} \\
\mathrm{Y}=85.3107-0.9464 \mathrm{x} \\
\mathrm{Y}=79.7718-0.9007 \mathrm{x} \\
\mathrm{Y}=70.9299-0.5640 \mathrm{x} \\
\mathrm{Y}=79.4199-0.8685 \mathrm{x}\end{array}$ & $\begin{array}{l}0.1241 \\
0.0632 \\
0.1843 \\
0.2832 \\
0.3499\end{array}$ & $\begin{array}{l}2.9569 \\
1.6344 \\
3.6159 \\
4.0966 \\
4.5480\end{array}$ \\
\hline $\begin{array}{l}\text { Percent Trimmed Fat } \\
34 \mathrm{~kg} . \\
55 \mathrm{~kg} . \\
92 \mathrm{~kg} \text {. (Pooled) } \\
\text { M } \\
\text { F }\end{array}$ & $\begin{array}{l}\mathrm{Y}=66.6713-3.2663 \mathrm{x} \\
\mathrm{Y}=70.4991-3.1524 \mathrm{x} \\
\mathrm{Y}=70.4170-0.7588 \mathrm{x} \\
\mathrm{Y}=66.4968-0.5435 \mathrm{x} \\
\mathrm{Y}=72.2480-0.8831 \mathrm{x}\end{array}$ & $\begin{array}{l}0.6925 \\
0.4236 \\
0.1120 \\
0.1797 \\
0.2482\end{array}$ & $\begin{array}{l}3.0847 \\
2.1318 \\
3.4274 \\
3.9836 \\
4.3942\end{array}$ \\
\hline
\end{tabular}

$\mathrm{S}_{\mathrm{b}}=$ Standard error of slope $\mathrm{b} ; \mathrm{S}_{\mathrm{y}} \cdot \mathrm{x}=$ sample standard deviation from regression,

TABLE 9

Relationship between some linear carcass measurements $[\mathrm{x}]$ and percentage lean $[\mathrm{Y}]$ in carcass of pigs slaughtered at three weights (Regression parameters)

\begin{tabular}{cccc}
\hline Carcass measurements & Prediction equations & $S_{b}$ & $S_{y} . x$ \\
\hline Carcass Length & & & \\
\hline $34 \mathrm{~kg}$. & $\mathrm{Y}=58.5378+0.0558 \mathrm{x}$ & 0.1671 & 3.3485 \\
$55 \mathrm{~kg}$ & $\mathrm{Y}=39.5237+0.3446 \mathrm{x}$ & 0.1309 & 2.3857 \\
$92 \mathrm{~kg}$ (Pooled) & $\mathrm{Y}=0.3657+0.7379 \mathrm{x}$ & 0.1332 & 3.5543 \\
$\mathrm{M}$ & $\mathrm{Y}=-4.9883+0.7961 \mathrm{x}$ & 0.2090 & 3.8757 \\
$\mathrm{~F}$ & $\mathrm{Y}=11.0079+0.6085 \mathrm{x}$ & 0.2354 & \\
Loin-Eye Muscle Area & & & \\
\hline $34 \mathrm{~kg}$ & $\mathrm{Y}=45.3972+1.1733 \mathrm{x}$ & 0.0901 & 2.1772 \\
$55 \mathrm{~kg}$ & $\mathrm{Y}=60.1612+0.5436 \mathrm{x}$ & 0.2319 & 2.3946 \\
$92 \mathrm{~kg}$ (Pooled) & $\mathrm{Y}=44.1364+0.6047 \mathrm{x}$ & 0.0868 & 3.4071 \\
$\mathrm{~F}$ & $\mathrm{Y}=42.9205+0.6325 \mathrm{x}$ & 01246 & 3.6758 \\
$\mathrm{~F}$ & & 0.1834 & 4.4462 \\
Mean Backfat Thickness & & & \\
\hline $34 \mathrm{~kg}$ & $\mathrm{Y}=68.9189-1.8698 \mathrm{x}$ & 0.3069 & 2.9388 \\
$55 \mathrm{~kg}$ & $\mathrm{Y}=85.3979-1.1228 \mathrm{x}$ & 0.0915 & 1.8039 \\
$92 \mathrm{~kg}$ (Pooled) & $\mathrm{Y}=67.9726-3.3384 \mathrm{x}$ & 0.7558 & 3.6570 \\
$\mathrm{M}$ & $\mathrm{Y}=61.5708-1.2803 \mathrm{x}$ & 1.2474 & 4.1646 \\
$\mathrm{~F}$ & $\mathrm{Y}=10.2930-3.6633 \mathrm{x}$ & 1.3623 & 4.5216 \\
\hline
\end{tabular}

$\mathrm{S}_{\mathrm{b}}=$ Standard error of slope, $\mathrm{b} ; \mathrm{S}_{\mathrm{y}} \mathrm{x}=$ sample standard deviation from regression. 
TABLE 10

Relationship between some predictors $(x)$ of carcass fatness and percentage fat $(Y)$ in carcass of pigs slaughtered at three weights (Regression parameters)

\begin{tabular}{cccc}
\hline Carcass fat Predictors & Prediction equations & $S_{b}$ & $S_{y} . x$ \\
\hline Percent Fat Cuts & & & \\
\hline $34 \mathrm{~kg}$ & $\mathrm{Y}=13.4163+0.4780 \mathrm{x}$ & 0.1317 & 3.1374 \\
$55 \mathrm{~kg}$ & $\mathrm{Y}=7.7575+0.8124 \mathrm{x}$ & 0.0756 & 1.4907 \\
$92 \mathrm{~kg}$ (Pooled) & $\mathrm{Y}=2.6171+1.1564 \mathrm{x}$ & 0.1210 & 2.3738 \\
$\mathrm{M}$ & $\mathrm{Y}=6.2288+1.0330 \mathrm{x}$ & 0.1691 & 2.4470 \\
$\mathrm{~F}$ & $\mathrm{Y}=-0.0800+1.2447 \mathrm{x}$ & 0.1578 & 2.0518 \\
Mean Backfat & & & \\
\hline $34 \mathrm{~kg}$ & $\mathrm{Y}=16.1130+3.1465 \mathrm{x}$ & 0.6286 & 3.0099 \\
$55 \mathrm{~kg}$ & $\mathrm{Y}=18.8789+2.1568 \mathrm{x}$ & 0.3426 & 1.7243 \\
$92 \mathrm{~kg}$ (Pooled) & $\mathrm{Y}=14.2011+5.0059 \mathrm{x}$ & 0.4719 & 2.2832 \\
$\mathrm{M}$ & $\mathrm{Y}=16.7062+4.3950 \mathrm{x}$ & 0.7387 & 2.4661 \\
$\mathrm{~F}$ & $\mathrm{Y}=13.4620+5.1000 \mathrm{x}$ & 0.5965 & 1.9797 \\
& & & \\
Percent Trimmed Fat & & & \\
\hline $34 \mathrm{~kg}$ & $\mathrm{Y}=14.8581+0.7482$ & 0.0994 & 2.7340 \\
$55 \mathrm{~kg}$ & $\mathrm{Y}=18.2872+0.4957$ & 0.0568 & 1.5992 \\
$92 \mathrm{~kg}$ (Pooled) & $\mathrm{Y}=14.1388+1.0051$ & 0.0576 & 1.7640 \\
$\mathrm{M}$ & $\mathrm{Y}=15.6166+0.9195$ & 0.0874 & 1.9380 \\
$\mathrm{~F}$ & $\mathrm{Y}=12.5171+1.1109$ & 0.0935 & 1.6554 \\
\hline
\end{tabular}

$\mathrm{S}_{b}=$ Standard error of slope $\mathrm{b} ; \mathrm{S}_{y} \cdot \mathrm{x}=$ sample standard deviation from regression.

Sofoluke and Dettmers (1973), that pigs carcasses produced at Ibadan are overfat and differ greatly from those reported elsewhere. The carcass values as well as the relative importance of the different measures of carcass leaness or fatness and the relationship among these various measures would appear to be in line with observations reported by several workers in many other countries of the world. There was however a noticeable tendency for the separable lean content as well as lean cuts to be higher in our report than many other reports from the temperates. Observations on sexual influences on carcass traits and relationships were similar. These point to the fact, that in attempting to develop standards for judging pig carcasses in the Nigerian situation, the considerable body of information that has accumulated elsewhere would be applicable. What needs to be one would be to relate these to the specified demands of the pork market and consumer preferences in this country. While such measures as direct chemical determinations or complete physical separation are considered the best measures of carcass quality, the magnitude of the correlation coefficients between separable lean or fat and the various cuts indicates that these could be used with some degree of precision in appraising carcasses resulting from experiments. Their use is particularly justified on the basis of their importance in measuring conformation. What need to be done is to clearly define the cuts, to keep the cutting errors to a minimum since the most impotant drawback of this technique lies in the fact that by their very nature, there must be considerable variation in such outs from place to place. A major advantage in their use lies in the fact that they leave the carcass in marketable and acceptable cuts as opposed to near mutilation in chemical analysis and complete physical separation. 


\section{REFERENCES}

Babatunde, G.M., Pond, W.G., Van Vleck, L.D., KROENING, G.H., REID, J.R, STOUFFER, J.R., and WeLLINGTON, G.H. 1966. Relationships among some physical and Chemical parameters of full - versus limited fed Yorkshire pigs slaughtered at different liveweights. J. Anim. Sci. 25, 526-531.

Babatunde, G.M., Pond, W.G., Van Vleck, L.D., KROENING, G.H. and REID, J.T. 1967. Effect of plane of nutrition, sex and bodyweight on the chemical composition of Yorkshire pigs. J. Anim. Sci. 26, 718-726.

Berry, B.W., Hillers, J.K. and Kroening G.H. 1968a. Effect of age on porcine muscle fiber diameter and carcass characteristics, Proc. Western Soc. Am. Soc. Anim. Science, 19, 199-204.

BERRY, B.W., HILLERS, J.K. and KROENING, G.H. 1968b. Vertebrae, Loin-eye and carcass measurements in Swine. Proc. Western Sec. Am. Soc. Anim. Science, 19, 217-222.

BuCK, S.F., HARRINGTON, G. and JoHNSON R.F. 1962. The prediction of lean percentage of pigs of bacon weight from carcass measurements. Anim. Prod. 4: 25-36.

Cumminas, J.N. and WinTers, L.M. 1951. A Study of factors related to carcass yield in Swine. Minn. Agr. Expt. Sta. Tech. Bull. 195.

DoORnEnBaL, H. 1961. The relationship between $\mathrm{Cr}^{51}$ determined redcell volume and the lean body mass in rats and pigs. Ph.D. Thesis. Cornell University, Ithaca, New York.

DoORNenBaL, H. 1967. Value of subcutaneous fat and backfat measurements on the live animal and the carcass as predictors of external, internal and total carcass fat in market weight pigs. J. Anim. Sc. 26, 42881295.

DOORNENBal, H., Wellington, G.H. and StoufFer, J.R. 1962. Comparison of methods used for carcass evaluation in swine. $f$. Anim. Sci. 21, 464-466.

DOORNENBAL, H. and MARTIN, A.H. 1966. The Association between commercial cut-out yield and gross chemical composition in market pigs. Anim. Prod. 8, 445-456.

DOORNENBAL, H. and FrANKHAM, R. 1970. A comparison of blood characteristics and backfat thickness as predictors of carcass composition of market weight pigs. Can. J. Anim. Sci. 50, 617-620.

DUNIEC, H.I.; KIELANOWSKI, J. and OsINSKA, Z. 1961. Heritability of chemical fat content in the loin muscle of baconers. Anim. Prod. 3, 195-201.
EMerson, J.A., PEARSON, A.M., Hoefer, J.A., MAGEE, W.T. and BRATZLER, L.J. 1964. Effects of slaughter weight upon the processing, characteristics, quality and consumer acceptability of pork carcasses and cuts. J. Anim. Sci. 23, 436-442.

Engelman, G., Dowell, A.A., Ferrin, E.F. and ANDERSON, P.A. 1950. Marketing slaughter hogs by carcass weight and grade. Minn. Agric. Exp. Sta. Tech. Bull. 187.

FIELD, R.A. VARNEY W.Y. and KEMP, J.D. 1961. Processing costs, market values and consumer acceptance of light and normal weight hogs. J. Anim. Sci. 20: 742-747.

FielD, R.A. 1971. Effect of castration on meat quality and quantity. J. Anim. Sci. 32, 849.

Freden, H.T., BerG, R.T., BOWLAND, J.P. and DOORNENBAL, H. 1964. Prediction of yield and value of hog carcasses. Can. J. Anim. Sci. 44, 334-346.

Gnaedinger, R.H., Pearson, A.M., Reineke, E.P. and Hix, V.M. 1963. Body composition of market weight pigs. J. Anim. Sci. 22, 495-500.

Grosse, F. \& Pfeiffer, H. 1963. Influence of environmental temperature on rate of gain, feed consumption and energy utilisation by the pig. Nutr. Abstr. Rev. 33, 1170.

Harkington, G. 1958. Pig carcass Evaluation. Techn. Communication No 12, Commonwealth Bureau of Animal breeding and genetics. Edinburgh.

HetZER, H.O. and MHLER, R.H. 1972. Rate of growth as influenced by selection for high and low fatness in swine. J. Anim. Sci. $35,730-742$.

Holmes, D.W. and Coey, W.B. 1967. The effects of environmental temperature and method of feeding on the performance and carcass composition of bacon pigs. Anim. Prod. 9, 209-218.

Jensen, A.H., BeCKer, D.E., Cox, J.L., GeHLBACH, G.D. HARMON, B.G. 1963. Some management and environmental factors affecting swine performance. J. Anim. Sci. 22, 1111 (Abstr.).

KLINE, E.A. and HAZEL, L.N. 1955. Loin-eye area at tenth and last rib as related to leaness of pork carcasses. J. Anim. Sci. 14, 659-663.

LidVAll, E.R., RAMSEY, C.B., SpeARS, B.G. and Fogleman, H.G. 1972. Predicting carcass. length of swine from live measurements. J. Anim. Sci. 35, 919-925. 
LODGE, G.A. 1969. "Quantitative and qualitative control of protein in meat animals" in PROTEINS AS HUMAN FOOD (Ed. R.A. Lawrie). Proc, 16th Easter School in Agricultural Science, 1969. University of Nottingham, Butterworths, London pp. 141166.

Orme, L.E., Pearson, A.M. Bratzler, L. J. MAGEE, W.T. and WHEELER, A.C. 1959 The muscle-bone relationship in beef. $J$. Anim. Sci. 18, 1271.

SeYmour, E.W., SPEER, V.C., HaYS, V.W. MANGOLD, D. W. HAZEN, T.E. 1964. Effects of dietary protein level and environmental temperature on performance and carcass quality of growing finishing swine. J. Anim. Sci. 23, 375-379.

SMTTH, G.C. and CAR-ENTER, Z.L. 1973. Evaluation of factors associated with the composition of pork carcasses. J. Anim. Sci. 36, 493-499.

Sofoluke, M.O. and Detrmers, A. 1973. Correlations of Weights and carcass trait with leaness in pigs. Niger. Agric. J., 10, 119-123.
SORENSON, P.H. 1962. Influence of climatic environment on pig performance. In Nutrition of Pigs and Poultry, Proc. Univ. of Notts. Eighth Eastern School in Agric. Sci. 1961. Ed. Morgan, J.T. and Lewis, D., Butterworths, London, pp. 88-103.

Strel, R.G.D. and Torrie, J.H. 1960. Principles and Procedures of Statistics. McGraw Hill Book Company, Inc., London.

TOPEL, D.G., MrRKel, R.A. and MACKINTOSH, 1965. Relationship between certain whole muscles and measures of pork carcass muscling. J. Anim. Sci. 24, 514-518.

Parney, W.Y., Kemy, J.D., Phillips, C.D. and BURNHART, C.E. 1962. Relative cut-out percentages and values of light and heavy weight hogs. J. Anim. Sci. 21, 593-596.

Zobrisky, S.E., LASLeY, J.F., BRAdy, D.E. and WeAVER, L.A. 1954 Pork carcass evaluation. Mo. Agric. Exp. Sta. Res. Bull. 554. 